\title{
Mangelfull legemiddelsamstemming i sjukehus
}

\section{Sjølv om det finst prosedyrar for legemiddelsamstemming, er dei utfordrande å setje i verk og har uklar ansvarsfordeling.}

\section{FORFATTERE}

Torill Kleppe

Sykehusfarmas $\varnothing \mathrm{yt}$

Universitetet i Bergen og Sykehusapotekene i Midt-Norge HF

Svein Haavik

Professor

Universitetet i Bergen

\section{Marit Kvangarsnes}

Professor

Helse Møre og Romsdal og NTNU

Torstein Hole

Klinikksjef

Helse Møre og Romsdal HF og NTNU

Anne-Lise Sagen Major

Avdelingsleder

Sykehusapotekene i Midt-Norge HF og NTNU

\section{SAMMENDRAG}

Bakgrunn: Ufullstendig informasjon om kva legemiddel pasienten brukar, kan vere eit problem for pasienttryggleiken ved innlegging på sjukehus.

Legemiddelsamstemming er ein metode som kan redusere dette problemet. Ved Ålesund sjukehus har ein gjennom fleire år og fleire prosjekt arbeidd med å skildre prosessen for legemiddelsamstemming, men det har vist seg å vere utfordrande å setje prosessen i verk.

Formål: Formålet med studien var å få innsikt i kva erfaringar legar og sjukepleiarar har med legemiddelsamstemming. Kunnskap om dette vil ha verdi i arbeidet med å utvikle gode rutinar for legemiddelsamstemming, og det kan dermed ha positive konsekvensar for pasienttryggleiken i sjukehus.

Metode: Semistrukturerte intervju med fem legar og fire sjukepleiarar som hadde erfaring med samstemming av legemiddelinformasjon blei gjennomført. Utvalet inkluderte både personale frå akuttmottak og medisinske sengepostar.

Resultat: Informantane erfarte at prosessen for legemiddelsamstemming er mangelfull. Dei formidla at dei nytta mange ulike kjelder til 
legemiddelinformasjon, og at dei ofte er usikre på om kjeldene reflekterer den faktiske legemiddelbruken til pasienten. Dei omtalte ein prosess for samstemming av legemiddelinformasjon med uklar ansvarsfordeling og manglande kommunikasjon og standardisering av oppgåvene.

Konklusjon: Legar og sjukepleiarar var samde om at legemiddelsamstemming er viktig for pasientane. Samstundes erfarte dei fleire utfordringar med upålitelege informasjonskjelder og mangelfulle rutinar. Dei formidla behov for klargjering av ansvar.

Legemiddelbehandling involverer fleire yrkesgrupper og tenestenivå, og dette gjer det særleg utfordrande å ha oversyn over kva behandlingsregime som gjeld for pasienten. Det er brei dokumentasjon på at manglande oversikt over legemiddelbruken til pasientar ved skifte av omsorgsnivå utgjer ein potensiell risiko for pasienttryggleiken (1-7).

\section{DET NORSKE PASIENTTRYGGLEIKSPROGRAMMET}

Fleire land og organisasjonar har dei siste åra utvikla eigne retningslinjer for legemiddelsamstemming (medication reconciliation) som eit ledd $\mathrm{i}$ å auke pasienttryggleiken (8-11). Det norske pasienttryggleiksprogrammet har samstemming av legemiddellister som eit av innsatsområda sine. Legemiddelsamstemming går ut på at ein i samarbeid med pasienten lagar ei nøyaktig og fullstendig liste over alle legemidla pasienten faktisk brukar (12).

Programmet skildrar kva tiltak som skal gjennomførast, og kva indikatorar ein kan måle på, men det seier ikkje noko om korleis legemiddelsamstemming skal utførast, korleis ein bør organisere prosessen, eller kva helsepersonellet bør ha av kunnskap for å utføre oppgåva. Dette må verksemda sjølv avgjere og setje i verk gjennom til dømes prosedyrar, leiing og opplæring av tilsette. Det har vist seg å vere både komplisert og utfordrande å setje i verk legemiddelsamstemming i sjukehus (13).

\section{STUDIER OM SAMSTEMMING AV LEGEMIDDELLISTER}

Ei amerikansk ekspertgruppe kom i 2010 med ei liste som tok for seg ti område som krev fokus for å lukkast (13). Nasjonalt kunnskapssenter for helsetenesta har publisert ei systematisk oversikt om samstemming av legemiddellister. Rapporten konkluderer med at legemiddelsamstemming truleg reduserer talet på uønskte avvik. Samstundes trekk den ingen konklusjon om korleis samstemming kan gjennomførast på ein effektiv måte (14).

I dei fleste studiane som er gjorde for å unders $\emptyset$ ke effekten av legemiddelsamstemming har kliniske farmasøytar spela ei sentral rolle i prosessen (15). Denne yrkesgruppa er til no svært avgrensa i norske sjukehus, og det er difor naudsynt å sjå på kva legar og sjukepleiarar kan bidra med. Vogelsmeier og medarbeidarar fann i fokusgruppeintervju med legar, sjukepleiarar og farmasøytar at omgrepet legemiddelsamstemming blei oppfatta ulikt avhengig av profesjon. I tillegg fann dei at det var uklart kven som var ansvarleg for prosessen (16).

Både klargjering av omgrep og roller blir av ekspertar trekt fram som viktig for å lukkast med legemiddelsamstemming (13). Andre barrierar for å setje i verk legemiddelsamstemming er upålitelege informasjonskjelder, at oppgåva blir prioritert ned blant helsepersonell, og at det kan vere dårleg kommunikasjon og samarbeid mellom profesjonar og mellom sjukehus og primærhelsetenesta. 


\section{KOMPLEKS PROSESS}

Ein prosess kan skildrast som eit komplekst organisatorisk fenomen, og prosessorientering vil seie at ein rettar søkelyset mot korleis medarbeidarar frå ulike einingar samarbeider om felles oppgåver (20). Legemiddelsamstemming er ein kompleks prosess som involverer fleire yrkesgrupper og avdelingar i sjukehuset. Prosessen startar som regel med at ein spør pasienten om kva legemiddel han brukar (legemiddelanamnese). Avhengig av omsorgsnivået til pasienten finst det $\mathrm{i}$ tillegg fleire andre aktuelle kjelder til legemiddelinformasjon.

\section{"Legemiddelsamstemming er ein kompleks prosess som involverer fleire yrkesgrupper og avdelingar i sjukehuset.»}

Ved Ålesund sjukehus har ein gjennom fleire år og fleire prosjekt arbeidd med å definere prosessen for legemiddelsamstemming og skildre han i prosedyrar. I 2011 blei det gjennomført ein deskriptiv studie der ein kartla kvaliteten på legemiddelinformasjonen etter innføring av ein prosedyre for legemiddelanamnese og opplæring av legar og sjukepleiarar $i$ akuttmottaket (3). Studien avdekte at nesten to tredelar av pasientane hadde manglande samsvar mellom legemiddellista på kurva og faktisk legemiddelbruk. For éin av fire pasientar var avviket klinisk relevant. Dette avveik frå forventningane ein hadde ved innføring av prosedyren.

\section{INVOLVERTE SENGEPOSTPERSONALET}

Med bakgrunn i desse resultata blei det i 2012 innført eit nytt tiltak der ein involverte sengepostpersonalet i prosessen med legemiddelsamstemming. Eit viktig element i prosessen var eit følgjeskjema som skulle fungere som eit dokumentasjons- og kommunikasjonsverktøy for dei ulike aktørane som bidrog i legemiddelsamstemminga. Ei kartlegging frå medisinsk avdeling i tidsrommet opp til 7 månader etter innføring av prosedyren viste at legemiddelsamstemming berre blei dokumentert gjennomført for 8 prosent av pasientane (21).

I kirurgisk klinikk valde ein å innføre prosedyren på tre forskjellige sengepostar samstundes, og det blei gjennomført ein prospektiv kontrollert studie. Delen pasientar med manglande samsvar mellom legemiddellista på kurva og faktisk legemiddelbruk blei redusert frå 53 til 25 prosent etter «implementeringsprosjektet» (22). Samanfatta viste studien at det er mogleg å få ned talet på feil i legemiddellistene til pasientane ved innlegging dersom ein jobbar systematisk med å hente inn og dokumentere legemiddelinformasjon. Dette oppnådde ein ved å gi sjukepleiarar på sengepostane opplæring i og ansvar innanfor legemiddelsamstemming.

\section{FORMÅLET MED STUDIEN}

Formålet med denne studien er å få innsikt i kva erfaringar legar og sjukepleiarar har med legemiddelsamstemming ved innlegging i sjukehus. Så vidt vi veit, er det ikkje gjennomført ein slik studie ved norske sjukehus tidlegare. Ettersom legemiddelsamstemming er avhengig av tverrprofesjonelt samarbeid og organisering, kan ein ikkje utan vidare overføre resultat frå utanlandske studiar til norske forhold. På tidspunktet då studien blei gjennomført, skilde prosedyrane på sjukehuset mellom omgrepa «legemiddelanamnese i mottak» og «legemiddelsamstemming på sengepost». Mottakspersonalet omtalte dermed sin del av oppgåva som legemiddelanamnese. I dag er omgrepa samla i éin prosedyre. Vi har difor valt å omtale heile prosessen som legemiddelsamstemming. Forskingsspørsmålet som blei formulert, var:

<<Kva erfaringar har legar og sjukepleiarar knytt til legemiddelsamstemming ved innlegging i 
sjukehus?>>

Kunnskap om dette vil ha verdi i arbeidet med å utvikle gode rutinar og læringskonsept for legemiddelsamstemming og kan få positive konsekvensar for pasienttryggleiken i sjukehus.

\section{METODE}

\section{DESIGN}

Studien har eit kvalitativt design (23). Det blei gjennomført intervju med legar og sjukepleiarar fordi vi ønskte å få data om kva erfaringar dei har med legemiddelsamstemming. Vi valde individuelle intervju fordi vi ønskte å forstå erfaringane til den enkelte (24).

\section{UTVAL}

Det blei gjort eit strategisk utval av legar og sjukepleiarar ved Ålesund sjukehus (23). Informantane blei rekrutterte av avdelingsleiaren. Vi valde å ta med begge yrkesgruppene sidan både legar og sjukepleiarar har oppgåver i legemiddelsamstemmingsprosessen. Utvalet var sett saman av sjukepleiarar og forskjellige legegrupper som turnuslege, legar i spesialisering (LIS-lege) og overlege, fordi dei har ulike roller i prosessen. Utvalet inkluderte både personale frå akuttmottak og medisinske sengepostar fordi vi ønskte å sjå på korleis dei ulike avdelingane samarbeidde i prosessen.

\section{DATAINNSAMLING OG ANALYSE}

Det blei gjennomført individuelle intervju med fem legar og fire sjukepleiarar (24). Intervjua blei gjennomførte i løpet av to veker i januar 2013 i Ålesund. Førsteforfattaren (TK) gjennomførte intervjua, som varte i 30-60 minutt. Med bakgrunn i tidlegare forsking $(3,22)$ utvikla vi ein semistrukturert intervjuguide med spørsmål knytt til legemiddelsamstemmingsprosessen. Vi brukte digital lydopptakar, og intervjua blei gjennomførte i eit møtelokale ved sjukehusapoteket. Vi avslutta intervjua då materialet blei vurdert som metta (25), og intervjua blei transkriberte til nynorsk utan dialektelement.

Vi gjennomførte analysen av datamaterialet ved systematisk tekstkondensering (24). Metoden har fire analysetrinn. Transkripsjonane blei først lesne for at vi skulle danne oss eit heilskapsinntrykk av materialet og identifisere førebelse tema. Vidare blei data som opplyste problemstillinga, organiserte i meiningsberande einingar og sorterte $\mathrm{i}$ kodegrupper (dekontekstualisering). I tredje analysetrinn blei kunnskapen, som blei etablert gjennom å kode dei meiningsberande einingane, abstrahert til tre kondensat. Til slutt samanfatta vi essensen i kvar av dei kondenserte gruppene i ein analytisk tekst (rekontekstualisering) som skildrar kva slags erfaringar helsepersonell hadde når det gjeld legemiddelsamstemmingsprosessen (24).

Både førsteforfattaren og sisteforfattaren analyserte materialet og diskuterte seg fram til tema og kodar i dei ulike analysetrinna. Sisteforfattaren hadde god kjennskap til prosessen gjennom arbeid med prosedyrar og opplæring av helsepersonell, medan førsteforfattaren blei kjend med prosessen gjennom studien.

\section{ETIKK}

Informert samtykke blei henta inn før intervjustart. Prosjektet var førehandsgodkjent av Norsk samfunnsvitenskapelig datatjeneste. Datamaterialet blei anonymisert, og lydopptak og namnelister blei sletta etter at studien var avslutta.

\section{RESULTAT}

Funna frå intervjua med fem legar og fire sjukepleiarar er framstilte i tre hovudtema: 1) ulike og upålitelege kjelder til legemiddelinformasjon, 2) behov for klargjering av ansvar og 3) 
manglande kommunikasjon og standardisering.

Vi har valt å framstille resultata frå dei ulike profesjonane og einingane samla fordi legemiddelsamstemming er ei oppgåve det blir samarbeidd om.

\section{ULIKE OG UPÅLITELEGE KJELDER TIL LEGEMIDDELINFORMASJON}

Legane og sjukepleiarane formidla at dei nytta fleire ulike kjelder når dei samlar inn opplysningar om legemiddelbruken til pasienten ved innlegging i sjukehus. Dette var fastlegeliste, innleggingsskriv frå fastlege eller legevaktlege, tidlegare journalnotat, epikriser, liste frå heimebasert omsorg eller sjukeheim, multidoselister og pasienten si eiga liste. Informantane sa dei stolte meir på lister frå heimebasert omsorg og sjukeheim enn fastlegelister og innleggingsskriv. Ein av legane sa det slik: «Listene som kjem frå sjukeheim eller heimetenesta, er oppdaterte på kva pasienten faktisk får, så det er ofte det som blir gullstandarden.»

\section{"Listene som kjem frå sjukeheim eller heimetenesta, er oppdaterte på kva pasienten faktisk får, så det er ofte det som blir gullstandarden.» \\ "Lege»}

Ein annan lege la vekt på at det er viktig å vurdere kva kjelde ein burde stole på i kvart enkelt tilfelle. Han var oppteken av at fastlegen i teorien skulle ha oversikt, men erfaringa hans tilsa noko anna. Ein av turnuslegane hadde hatt ein pasient som brukte heilt andre medisinar enn det som stod i innleggingsskrivet: «Seinast siste vakt kom det ein pasient rett frå fastlegen. Slik eg forstod det, hadde ho vore til hyppige kontrollar, men pasienten hadde si eiga liste på ein papirlapp som ikkje stemte med fastlegen si liste.» Dei erfarne legane uttrykte store forventningar til IKT-løysingar som til dømes kjernejournal og meinte at det ville løyse utfordringane med ulike lister.

Pasienten blei framheva som ei viktig kjelde til informasjon, men erfaringane var også at pasientane ikkje alltid har full oversikt over legemiddelbruken sin. Ein lege sa det slik: «Når gjennomsnittsalderen er $\mathrm{h} \varnothing \mathrm{g}$ og medisinane mange, slik som det er for veldig mange, så er det avgrensa kor mykje informasjon pasienten sjølv har om sine eigne medisinar.» Eit gjennomgåande trekk i intervjua var at det ikkje fanst ein felles standard for korleis ein snakka med pasienten om legemiddelbruk. Det verka tilfeldig og opp til kvar enkelt korleis ein gjorde det. Det blei framheva at alle burde bli flinkare til å spørje spesifikt om pasientane faktisk tek medisinane som står på listene, og om dei tek andre medisinar - til dømes reseptfrie legemiddel.

\section{BEHOV FOR KLARGJERING AV ANSVAR}

Både legar og sjukepleiarar formidla at legane er ansvarlege for legemiddelbehandlinga $i$ sjukehuset, men at det er eit felles ansvar å sikre at opplysningane om legemiddelbruken til pasienten blir korrekt. Det blei framheva at legemiddelsamstemming er viktig, men fleire hadde vanskar med å definere kven som hadde ansvar for kva i legemiddelsamstemmingsprosessen - spesielt gjaldt dette på sengepost. Ein av legane sa han ikkje trudde at ansvaret for legemiddelsamstemming var tildelt ei bestemt yrkesgruppe. Ein av sjukepleiarane uttrykte seg slik: «Så eg vil seie at vi er eit team, eg. Litt er vårt ansvar og litt er legen sitt ansvar».

I mottak verka arbeidsfordelinga tydeleg. Sjukepleiarane fortalde at dei fann fram følgjeskjemaet og henta inn legemiddellister, medan turnuslegane sa at dei snakka med pasienten og skreiv kurve. Turnuslegane gav uttrykk for at pasientintervjuet var ei prioritert oppgåve i mottak, men at pasientane ofte var stressa, og at det var tidspress for 
helsepersonellet. Dette gjorde det vanskeleg å samle fullstendig oversikt over legemiddelbruken. Erfaringane var at ein ofte treng meir tid enn ein har til rådvelde i mottak for å finne ut av dette.

Legane i mottak forventa at dette blei tatt tak i på sengepost i rolegare omgivnader, men dei sa dei var usikre på om det faktisk blei gjort. Ein av turnuslegane formidla eit behov for kvalitetssikring av legemiddelinformasjonen på sengepost og klargjering av kven sitt ansvar dette er: «Ein må sjå på korleis ein kan kvalitetssikre at legemiddelinformasjonen blir følgd opp på post. Det trur eg er viktig. Det kan hende det er definert kven si oppgåve det er å sjekke opplysningane når ein kjem på post, men det må bli tydelegare kven sitt ansvar det er.»

\section{«I intervjua kom det fram at det var uklart kven som skal gjere kva på sengeposten.»}

I intervjua kom det fram at det var uklart kven som skal gjere kva på sengeposten. Oppgåver som å intervjue pasientane og hente inn lister såg ikkje ut til å vere tildelt spesifikke arbeidsgrupper. Sjukepleiarane sa at dei tok imot pasienten når han kjem frå mottak, og forklarte at dei ofte nytta denne situasjonen til å snakke om medisinar. Det blei også formidla at dei var involverte i å kontakte fastlegekontor og heimesjukepleie for å få inn medisinlister. Sjølv om sjukepleiarane sa at dei var opptekne av legemidla, sa dei samstundes at legemiddelsamstemminga var avhengig av tid og ressursar. Oppgåva blei ikkje prioritert i travle situasjonar. Fleire av informantane, både legar og sjukepleiarar, peikte på at kliniske farmasøytar kunne vere ei støtte i legemiddelsamstemmingsprosessen, men det kom også fram at ansvaret ikkje burde bli tillagt denne gruppa, fordi dei ikkje alltid er til stades på sengeposten.

\section{MANGLANDE KOMMUNIKASJON OG STANDARDISERING}

Informantane var kjende med at formålet med følgjeskjemaet er kommunikasjon om legemiddelbruk. Mottakspersonalet fortalde at dei skreiv ned beskjedar som gjeld manglande lister eller usikker informasjon på skjemaet. Samstundes sa dei at legemiddelsamstemmingsprosessen bar preg av dårleg kommunikasjon, og av at ein trudde og ikkje visste kva andre gjorde. Det blei framheva at legane brukte skjemaet til å formidle uvisse dersom situasjonen i mottak ikkje tillét full oppklaring, men det kom også fram at dei var usikre på om beskjedane blei følgde opp på sengepost.

Ein LIS-lege formulerte seg slik: «Eg hugsar at eg synest det var veldig trygt og godt å ha skjemaet i akuttmottaket. Viss det var noko eg var usikker på, så var det faktisk nokon som skulle sjekke det opp. Ja, burde sjekke det opp i alle fall.» I intervjua med sengepostpersonalet kom det fram at det var tilfeldig om det som stod på skjemaet, blei fanga opp på sengeposten. Sjukepleiarane formidla at dersom skjemaet låg fremst $\mathrm{i}$ pasientmappa og det ikkje var for travelt, kunne beskjedane bli fanga opp av sjukepleiaren ved mottak på sengepost. Viss ikkje kom det fram at neste sjekkpunkt var previsitten neste dag, der lege og sjukepleiar fordeler oppgåver seg imellom, men verken legane eller sjukepleiarane sa dei var særleg merksame på skjemaet.

Ein av legane meinte at beskjedar ikkje alltid nådde fram. «Eg trur det er ofte at det glepp. Dersom det står at ein skal sjekke opp noko, blir det likevel ikkje gjort fordi ein ikkje har rutinar for å leite etter skjemaet.» Det kom også fram at opplysningar om legemiddelbruk blei kommunisert på andre måtar enn på skjemaet - til dømes på gule lappar og i innkomstjournal. Det blei sagt at i previsitten tok legane utgangspunkt i det som stod på kurva, og ein av legane meinte at informasjonen burde knytast hit: «Eg tenker at det beste er 
å få det på kurva dersom noko må sjekkast opp, fordi du ikkje kjem gjennom ein previsitt utan å ha sett på han.»

\section{DISKUSJON}

Funna i denne studien viser at både legar og sjukepleiarar erfarte at prosessen for legemiddelsamstemming var mangelfull. Dei formidla at dei nytta mange ulike kjelder til legemiddelinformasjon ved innlegging, og at dei ofte var usikre på om dei reflekterer den faktiske legemiddelbruken til pasienten. Dei omtalte ein prosess for samstemming av legemiddelinformasjon med uklar ansvarsfordeling og manglande kommunikasjon og standardisering av oppgåvene. Dette er i samsvar med aktuell litteratur (13, 16-19).

Både nasjonal og internasjonal forsking viser at det er god grunn til å vere kritisk til kva kjelder ein bør konsultere for å få oversikt over legemiddelbruken til pasienten (1-7, 26). Trass i uvissa blant helsepersonellet og kunnskapen om hòla i systemet, fann vi ikkje at dei var kritiske på ein systematisk måte. Verken turnuslegane eller sjukepleiarane på sengepost gav inntrykk av at det eksisterte ein felles standard for korleis ein snakka med pasienten om legemiddelbruken. Oppsummeringa frå kunnskapssenteret viser at legemiddelsamstemming truleg reduserer uønskte avvik når det blir gjennomført på ein standardisert måte (14).

\section{KAN KJERNEJOURNALEN HJELPE?}

Informantane i denne studien uttrykte manglande tillit til informasjonskjeldene, og fleire av legane hadde store håp til kjernejournalen (27) som no er innført i Noreg. Kjernejournal har blitt ei viktig kjelde til legemiddelinformasjon ved innlegging i sjukehus.

Legemiddelinformasjonen ein finn der, blir henta frå reseptformidlaren, som er databasen for e-reseptar. Kvaliteten på informasjonen er difor avhengig av at legane oppdaterer reseptinformasjonen i reseptformidlaren. Helsepersonell som skal gjere legemiddelsamstemming, må difor vere kritiske til informasjonen dei finn i kjernejournalen. Ikkje minst vil det framleis vere avgjerande at helsepersonell snakkar med pasienten for å finne ut kva legemiddel han faktisk tek, korleis han tek dei, og om han tek reseptfrie legemiddel eller kosttilskot $\mathrm{i}$ tillegg. Resultata våre tydde på at dette hadde forbetringspotensial i 2013. Boockvar og medarbeidarar fann gjennom intervju med legar og farmasøytar at elektroniske kjelder kunne føre til at ein i mindre grad snakka med pasienten fordi ein stolte for mykje på IT-verktøyet (18).

\section{MOTTAKSSITUASJONEN}

I studien blei det gitt uttrykk for at mottakspersonellet var godt organisert og hadde ei klar ansvarsfordeling når det gjaldt innsamling av legemiddelinformasjon. Ein kan likevel spørje seg om situasjonen og kompetansen i akuttmottaket er tilpassa denne oppgåva.

Sjukepleiarane fortalde at dei bidrog til å få tak i medisinlister frå fastlege, heimesjukepleie og sjukeheimar, men naturleg nok er dette avhengig av tilgang til kjelder som til dømes opningstider. Mottakssituasjonen kan tidvis vere kaotisk, og utgreiing må ofte gå fort. Turnuslegane, som møter pasienten først, er i tillegg dei minst erfarne legane i sjukehuset.

\section{«Informasjon om legemiddel blei kommunisert på fleire måtar - til dømes gjennom kurve, følgjeskjema, innkomstjournal og gule lappar.»}

Vi fann at legane i mottak formidla uvisse om legemiddelbruk på følgjeskjemaet, men verken legar eller sjukepleiarar på sengepost sa dei var særleg merksame på skjemaet. Dette kan tyde på at det på studietidspunktet blei etablert ei sanning om kva legemiddel pasienten stod på i akuttmottaket, og at det ikkje blei stilt spørsmål ved dette på ein systematisk måte på sengeposten. Resultata våre viste at informasjon om legemiddel blei kommunisert på 
fleire måtar - til dømes gjennom kurve, følgjeskjema, innkomstjournal og gule lappar. Ein slik mangel på standardisering er med på å gjere legemiddelsamstemmingsprosessen endå meir kompleks. Vi meiner det vil vere avgjerande å kome fram til einsarta løysingar når det gjeld kommunikasjon om legemiddel og intern forordning ved framtidig utvikling av IKT-Iøysingar i sjukehus.

\section{PRIORITERING AV OPPGÅVER}

Kvalitativ forsking frå andre land har vist at manglande bevisstheit og kunnskap blant helsepersonell om kva legemiddelsamstemming er, kan vere ein barriere for å setje prosessen i verk (17). I vår studie var både legar og sjukepleiarar einige om at legemiddelsamstemming er viktig, og det var ikkje spørsmål om det skulle gjerast eller ikkje. Likevel fann vi at det blei nedprioritert i travle periodar. Prioritering av andre oppgåver som blir vurdert som viktigare, er ein annan barriere for å setje prosessen i verk (18). Legemiddelsamstemming er forskriftsfesta, og i tillegg har Helse Møre og Romsdal skildra prosedyrane i kvalitetssystemet sitt.

Legemiddelhandteringsforskrifta $§ 5$ lyder: «En oppdatert og samstemt liste over legemiddel i bruk skal, i forståelse med pasienten, alltid følge pasienten ved skifte av omsorgsnivå» (28). Dei overordna nivå 1-prosedyrane for legemiddelsamstemming i Helse Møre og Romsdal gjeld for alt helsepersonell som er involvert i prosessen. På tidspunktet for studien var det definert kva sengepostpersonellet skulle gjere, men det var ikkje definert kven som skulle gjere kva i prosessen. Funna våre stadfesta at oppgåvene knytt til legemiddelsamstemming på sengepost ikkje var tildelt spesielle yrkesgrupper eller var standardisert på nokon måte. Samstundes viste funna at sjukepleiarane var innstilte på å ta del i både å hente inn skriftlege kjelder og intervjue pasientar.

\section{KLARGJERING AV ROLLER OG ANSVAR}

I ein studie som blei gjennomført ved kirurgisk avdeling ved same sjukehus, blei legemiddellistene rettare då sjukepleiarar på sengepost samla inn legemiddelinformasjon (22). I forkant av prosjektet fekk sjukepleiarane undervisning av farmas $\varnothing y t$ som også var til stades i avdelinga gjennom prosjektperioden. Dei fekk ikkje tildelt meir sjukepleieressursar for å gjere oppgåva (22). I ein prosess vil ein person gjere noko med ei sak basert på kompetansen sin, ansvaret sitt og fullmaktene sine (20). Vi trur difor at å setje legemiddelsamstemming i system i stor grad handlar om å definere roller, plassere ansvar og å sørgje for at helsepersonellet er godt opplært i legemiddelsamstemming. Likevel er dette truleg ikkje nok for å oppnå varig betring.

I tillegg til klargjering av roller og ansvar listar Greenwald og medarbeidarar opp ni andre område som treng merksemd dersom ein skal lukkast med å setje i verk legemiddelsamstemming (13). Legemiddelsamstemming kan fremje behov for større endringar i tradisjonelle roller (29) - til dømes at sjukepleiarar får ansvar knytt til legemiddelsamstemming. Dette bør ein ta omsyn til, og vi trur det er avgjerande å utvikle gode læringskonsept. Vi meiner det bør leggast vekt på kritisk vurdering av kjelder til legemiddelinformasjon i tillegg til kommunikasjonstrening med pasienten for å få oversyn over faktisk legemiddelbruk.

Ein pasient som blir lagd inn akutt i sjukehus, kjem i kontakt med fleire avdelingar og fleire tilsette, og ein er difor avhengig av god informasjonsflyt og kommunikasjon om legemiddelbruken. Studien vår viser at dette kan bli betre. Legemiddelsamstemming er avhengig av god kommunikasjon mellom den som hentar inn legemiddelinformasjon, og legen som skal vurdere og ta stilling til kva pasienten skal ha av legemiddel. Legemiddelsamstemming ved innlegging er først utført når legemiddelinformasjonen som blir henta inn, aktivt er vurdert av lege og overført til kurva eller journalen til pasienten (12). 
Det er difor avgjerande at beskjedane mellom sjukepleiarar og legar, og mellom mottak og sengepost, blir sende og oppfatta. Følgjeskjemaet var tenkt å fungere som ein stafettpinne for overføring av slike beskjedar, men resultata våre viste at dette ikkje fungerte optimalt.

\section{STYRKAR OG AVGRENSINGAR}

Studien tok utgangspunkt i både legar og sjukepleiarar frå mottak og sengepost sine erfaringar med legemiddelsamstemming. Vi valde individuelle intervju som metode fordi vi $\emptyset n$ nkte å forstå dei enkelte informantane si erfaring. Denne metoden gir berre indirekte informasjon om kva som faktisk skjer i prosessen (24). Ved å velje observasjon eller fokusgruppeintervju som metode kunne vi moglegvis ha fått meir data om sjølve samhandlinga i legemiddelsamstemmingsprosessen. Det ville også vore interessant.

Informantane blei intervjua i eit uforstyrra møterom på sjukehusapoteket. Vi meiner dette var ein styrke fordi informantane var borte frå dei daglege aktivitetane sine. Forfattargruppa var tverrprofesjonelt samansett og ingen har sjølv delteke i legemiddelsamstemmingsprosessen. Dette var ein styrke i utforming av forskingsspørsmål, analyse og tolking av data. Sjølv om studien er utført ved Ålesund sjukehus er det truleg at funna har overføringsverdi til andre sjukehus fordi legemiddelprosessen i stor grad organiserast på same måte ved dei ulike sjukehusa. Det er difor rimeleg å tru at andre sjukehus også vil ha nytte av kunnskapen frå denne studien.

\section{IMPLIKASJONAR FOR PRAKSIS}

Medisinsk avdeling i Ålesund har sett søkelys på rett legemiddelbruk i fleire år, og dei har hatt klinisk farmasøyt i avdelinga sidan 2010. Resultata frå denne studien har, gjennom betringsprosjekt i klinikken, bidrege til vidareutvikling av rutinane for legemiddelsamstemming. Dette har hatt mykje å seie for praksis og er i tråd med tilrådingane frå kunnskapssenteret (14). I tillegg har området, gjennom pasienttryggleiksprogrammet (12), fått meir vekt frå leiinga. Då dei byrja å etterspørje resultat, auka legemiddelsamstemmingsprosenten dramatisk (30).

Ifølgje arbeidsmodellen til Iden, som har tre hovuddelar (styring, ressursar og arbeids- og informasjonsflyt), er det i tillegg til å definere aktivitetssettet i prosessen vel så viktig å konkretisere kven (rollene) som inngår i prosessen og relasjonane mellom dei (20). Innarbeiding av nye rutinar er eit komplekst arbeid som er avhengig av fleire faktorar som gjeld organisasjonen, dei tilsette og leiarane, i tillegg til sjølve prosessen (31). I dag skjer det eit stadig arbeid med motivasjon og opplæring av helsepersonell, der det siste er produksjon av ein film om temaet (32) og eit e-læringskurs. I det vidare arbeidet vil det vere interessant å sjå nærare på styringsdelen av arbeidsmodellen til Iden, som påpeiker at for å forvalte og vidareutvikle ein prosess må nokon vere ansvarleg for prosessen som heilskap (20).

\section{KONKLUSJON}

Legar og sjukepleiarar var samde om at legemiddelsamstemming er viktig for pasientane. Samstundes erfarte dei fleire utfordringar. Fleire ulike og upålitelege kjelder til legemiddelinformasjon kombinert med manglande rutinar for gjennomføring gjorde prosessen mangelfull. Resultata frå denne studien har vore viktige i arbeidet med å etablere gode rutinar for legemiddelsamstemming. Viktige element som kom fram i studien, var behov for standardisering av oppgåvene, betring av kommunikasjon og plassering av ansvar. Det er behov for vidare forsking for å undersøke om slike tiltak vil vere med å auke pasienttryggleiken i sjukehus.

\section{REFERANSAR}

1. Chan AH, Garratt E, Lawrence B, Turnbull N, Pratapsingh P, Black PN. Effect of education on the recording of medicines on admission to hospital. J Gen Intern Med 
2. Cornish PL, Knowles SR, Marchesano R, Tam V. Unintended Medication Discrepancies at the Time of Hospital Admission. Arch Intern Med 2005;165:424-9.

3. Fagervoll K-A, Lim S, Liaaen ED, Seljeseth YM, Holst L, Major A-L. Kvalitet av legemiddelanamnese tatt opp ved innleggelse på sykehus. Norsk Farmasøytisk Tidsskrift 2013(13):38-42.

4. Frydenberg K, Brekke M. Kommunikasjon om medikamentbruk i henvisninger, innleggelsesskriv og epikriser. Tidsskr Nor Laegeforen 2011;131(9-10):942-5.

5. Nilsson N, Lea M, Lao Y, Wendelbo K, Gløersen G, Mowé $M$, et al. Medication discrepancies revealed by medication reconciliation and their potential short-term and long-term effects: a Norwegian multicentre study carried out on internal medicine wards. European Journal of Hospital Pharmacy 2015;22 (5):298-303.

6. Rognstad S, Straand J. Vet fastlegen hvilke medisiner hjemmesykepleien gir pasientene? Tidsskrift for Den Norske Legeforening 2004;124(6):810-2.

7. Tam VC, Knowles SR, Cornish PL, Fine N, Marchesano R, Etchells EE. Frequency, type and clinical importance of medication history errors at admission to hospital: a systematic review CMAJ. 2005;173(5):510-5.

8. World Health Organization (WHO). Action on Patient Safety - High 5s. Tilgjengeleg frå: http://www.who.int/patientsafety/implementation/solutions/high5s/en/ (lasta ned 30.06.2016).

9. Institute for Healthcare Improvement (IHI). Medication Reconciliation to Prevent Adverse Drug Events. Tilgjengeleg frå: http://www.ihi.org/topics/ADEsMedicationReconciliation/Pages/default.aspx (lasta ned 30.06.2016).

10. National Institute for Health and Clinical Excellence (NICE). Technical patient safety solutions for medicines reconciliation on admission of adults to hospital 2007. Tilgjengeleg frå: https://www.nice.org.uk/sharedlearning/medicines-reconciliation (lasta ned 30.06.2016).

11. The Joint Commission. Sentinel Event Alert, Issue 35: Using medication reconciliation to prevent errors 2006. Tilgjengeleg frå:

http://www.jointcommission.org/sentinel_event_alert_issue_35_using_medication_reconciliation_to_prevent_errors/ (lasta ned 30.06.2016).

12. Pasientsikkerhetsprogrammet. Samstemming av legemiddellister 2016. Tilgjengeleg frå: http://www.pasientsikkerhetsprogrammet.no/no/I+trygge+hender/Innsatsomr\%C3\%A5der/Samstemming+av+legemiddellister.16.cms (lasta ned 30.06.2016).

13. Greenwald JL, Halasyamani L, Greene J, LaCivita C, Stucky E, Benjamin B et al. Making inpatient medication reconciliation patient centered, clinically relevant and implementable: a consensus statement on key principles and necessary first steps. J Hosp Med 2010;5(8):477-85.

14. Holte H. Oppsummering av systematiske oversikter om effekt av samstemming av legemiddellister. Rapport fra Kunnskapssenteret nr. 7/2015, Systematisk oversikt. 2015. 
15. Lo L, Kwan J, Fernandes OA, Shojania KG. Medication Reconciliation Supported by Clinical Pharmacists. Making Health Care Safer II: An Updated Critical Analysis of the Evidence for Patient Safety Practices: Agency for Healthcare Research and Quality; 2013.

16. Vogelsmeier A, Pepper GA, Oderda L, Weir C. Medication reconciliation: A qualitative analysis of clinicians' perceptions. Res Social Adm Pharm 2013;9(4):419-30.

17. van Sluisveld N, Zegers M, Natsch S, Wollersheim H. Medication reconciliation at hospital admission and discharge: insufficient knowledge, unclear task reallocation and lack of collaboration as major barriers to medication safety. BMC Health Serv Res 2012;12.

18. Boockvar KS, Santos SL, Kushniruk A, Johnson C, Nebeker JR. Medication reconciliation: barriers and facilitators from the perspectives of resident physicians and pharmacists. J Hosp Med 2011;6(6):329-37.

19. Lee KP, Hartridge $C$, Corbett $K$, Vittinghoff $E$, Auerbach AD. "Whose job is it, really?» Physicians', nurses', and pharmacists' perspectives on completing inpatient medication reconciliation. J Hosp Med 2015;10(3):184-6.

20. Iden J. Prosessledelse: Fagbokforlaget; 2013.

21. Kleppe T. Legemiddelanamnese og legemiddelsamstemming ved Ålesund sjukehus. 2013.

22. Holler JG, Helgesen KS, Aarset M, Major A-L. Legemiddelsamstemming - et tiltak som virker. Sykepleien Forskning. 2015;1. Tilgjengeleg frå: https://sykepleien.no/forskning/2015/02/et-tiltak-som-virker (lasta ned 15.06.2017).

23. Pollit D, Beck C. Nursing Research: Generating and Assessing Evidence for Nursing Practice: Lippincott, Williams, \& Wilkins; 2008.

24. Malterud K. Kvalitative metoder i medisinsk forskning. En innføring. 3. utgave, Oslo: Universitetsforlaget; 2013.

25. Malterud K, Siersma VD, Guassora AD. Sample Size in Qualitative Interview Studies: Guided by Information Power. Qual Health Res. 2016, 26 (13), 1753-1760.

26. Wekre L, Spigset O, Sletvold O, Sund JK, Grimsmo A. Multidose drug dispensing and discrepancies between medication records. Qual Saf Health Care 2010;19(5):e42.

27. Direktoratet for e-helse. Kjernejournal. Tilgjengeleg frå: https://helsenorge.no/kjernejournal (lasta ned 28.12.2016).

28. Lovdata. Forskrift om endring i forskrift om legemiddelhåndtering for virksomheter og helsepersonell som yter helsehjelp. 23. november 2014 nr. 1455. Tilgjengeleg frå: https://lovdata.no/dokument/LTI/forskrift/2014-11-23-1455 (lasta ned 30.06.2016).

29. Sanchez SH, Sethi SS, Santos SL, Boockvar K. Implementing medication reconciliation from the planner's perspective: a qualitative study. BMC Health Serv Res 2014;14:290.

30. Nilsen L. Gikk fra 7-80 \% samstemte legemiddellister. Dagens Medisin. 24.02.2015.

31. Konsmo T. Hvordan skape vedvarende forbedringer? Helsebiblioteket 2015. 
Tilgjengeleg frå:

http://www.helsebiblioteket.no/kvalitetsforbedring/slik-kommer-du-i-gang/verkt\%C3\%B8y/verkt\%C3\%B8y-for-vedvarende-forbedringer-sustainab ility (lasta ned 06.01.2016).

32. Hegle H. Legemiddelsamstemming ved Ålesund sjukehus. Tilgjengeleg frå: https://vimeo.com/153702879 (lasta ned 28.12.2016). 